\title{
Estimation of Correlation and Path Analysis between Seed Yield and Various Quantitative Traits in Black Sesame (Sesamum indicum L.)
}

\author{
Ayushi Jaiswal $^{1 *}$ and Rajani Bisen ${ }^{2}$ \\ ${ }^{1}$ Department of Genetics and Plant Breeding, ${ }^{2}$ Project Coordinating Unit (Sesame and Niger), \\ JNKVV, Jabalpur, India \\ *Corresponding author
}

\section{A B S T R A C T}

Keywords

Sesame,

Correlation, Path coefficient, Seed yield

\section{Article Info}

Accepted: 12 December 2020 Available Online: 10 January 2021
Seventy genotypes of sesame were studied by correlation and path coefficient analysis for single plant yield and other yield contributing components. The association between seed yield and its contributing characters indicated that the seed yield per plant had positive and significant association with number of capsules per plant, number of primary branches per plant also thousand seed weight, harvest index and number of primary branches per plant. Based on path analysis, the number of capsules per plant, days to $50 \%$ flowering, number of primary branches per plant, number of seed per capsules and harvest index showed significant positive direct effect with seed yield per plant. Therefore, the number of capsules per plant and number of primary branches per plant should be given importance in selection programmes to get high seed yield in sesame.

\section{Introduction}

Sesame (Sesamum indicum L., 2n=26), an oleaginous seed of the family Pedaliaceae diploid species with $2 n=26$ is one of the oldest oil crops and is widely cultivated in Asia and Africa, primarily for its high oil content and its distinctive flavor. The largest global producers of sesame seed are India, China and Sudan contributing approximately $60 \%$ of world production, and are highly valued for their oil. Sesame seed is commonly known as the "Queen of the Oil seeds". The seeds of sesame contain 40 to 53 percent oil, which is rich in antioxidants and has amount of oleic and linoleic acids. The seed is additionally plentiful in protein, minerals, nutrients, including niacin and lignans, for example, sesamolin and sesamin.

Considering its broad spectrum range of consumption, there is continuous need to increase the yield potential to make it a more profitable crop. Several researchers viz., Goudappagoudra et al., (2011), Abate and Mekbib (2015), Saxena and Bisen (2016) Parameshwarappa et al., (2009) Ibrahim and Khidir (2012), Gangadhara et al., (2012), Bharathi et al., (2015) and Abhijatha et al., (2017) have employed different genetic 
parameters and worked out association analysis to generate information for planned breeding programme.

Yield component and plant trait contribution on seed yield may be important for breeding strategies. Correlation analysis that relates seed yield to a single variable may not provide a complete understanding of importance of each component in determining seed yield (Dewey \& Lu, 1959; Singh et al., 1979). Path coefficient analysis allows an effective mean of partitioning correlation coefficients into unidirectional pathway and alternate pathway. This analysis permits a critical examination of specific factors that produce a given correlation and can be successfully employed in formulating an effective selection strategy through correlation and path coefficient analysis. Goudappagoudra et al., (2011) observed that seed yield per plant, number of capsules per plant, number of seeds, number of branches per plant, plant height and 1000 seed weight are seed yielding traits. Selection for these characters may be useful in increasing seed yield in sesame.

Therefore, the plant breeder must know the relationship between different contributing and their association with yield. Keeping the above points into consideration, the present investigation was undertaken (i) to evaluate associations between yield components and plant traits with seed yield and (ii) to determine direct and indirect effects of yield components and plant traits on seed yield in black sesame genotypes.

\section{Materials and Methods}

The experiment was conducted under Project Coordinating Unit (Sesame and Niger) Research Farm, JNKVV, Jabalpur (M.P.) during kharif 2017. The soil of the experimental area is medium black with uniform topography and free from water logged conditions. Jabalpur is located in the Mahakoshal region of Madhya Pradesh and has sub-tropical and semi-arid climate having hot and dry summer and cold winter with occasional showers. The experimental material consisted of 70 black sesame genotypes laid out in a Randomized Block Design in three replications with spacing of $30 \times 10 \mathrm{~cm}$. The crop was raised following the recommended package of practices. The observations were recorded on days to flower initiation, days to $50 \%$ flowering, days to maturity, plant height, number of primary branches per plant, number of secondary branches per plant, number of capsules per plant, number of seeds per capsule, thousand seed weight, seed yield per plant, harvest index and oil content (\%). Soxhlet apparatus was used to extract oil from sesame seed. The data were subjected to statistical analysis. Genotypic and phenotypic correlation coefficients were calculated according to the formula suggested by (Miller et al., 1958). Path coefficients were estimated by following Dewey and Lu, 1959. The estimates of correlation coefficient and path coefficient analysis were calculated by analyzing data using INDOSTAT statistical package.

\section{Results and Discussion}

Phenotypic and genotypic correlations between seed yield per plant and various yield traits viz., days to flower initiation, days to $50 \%$ flowering, plant height, number of primary branches per plant, number of secondary branches per plant, number of capsules per plant, days to maturity, number of seeds per capsule, 1000 seed weight, harvest index (\%) and oil content (\%) are presented in Table 1. The results revealed that the estimates of genotypic correlation coefficients were higher than the phenotypic correlation coefficients. 
Table.1 Phenotypic and Genotypic correlation analysis for yield and yield related traits in sesame genotypes

\begin{tabular}{|c|c|c|c|c|c|c|c|c|c|c|c|c|c|}
\hline \multicolumn{2}{|c|}{ Character } & DIF & DF $50(\%)$ & DM & PH & NPBPP & NSBPP & NCPP & NSPC & $1000 \mathrm{SW}$ & HI (\%) & OC $(\%)$ & SYPP \\
\hline \multirow[t]{2}{*}{ DIF } & $\mathrm{P}$ & 1.0000 & $0.9789 * * *$ & 0.0284 & $-0.1732 *$ & $-0.1746 *$ & -0.1048 & $0.2080 * *$ & -0.1242 & 0.0062 & 0.0383 & 0.0904 & 0.0576 \\
\hline & $\mathrm{G}$ & 1.0000 & 0.9925 & 0.0188 & -0.1924 & -0.3191 & -0.1444 & 0.2147 & -0.1850 & -0.0009 & 0.0152 & 0.0920 & 0.0503 \\
\hline \multirow[t]{2}{*}{ DF $50(\%)$} & $\mathrm{P}$ & & 1.0000 & 0.0453 & $-0.1783 * *$ & $-0.1726 *$ & -0.1251 & $0.1945 * *$ & $-0.1383 *$ & -0.0120 & 0.0554 & 0.1234 & 0.0547 \\
\hline & G & & 1.0000 & 0.0357 & -0.2054 & -0.3288 & -0.1439 & 0.1991 & -0.1858 & -0.0515 & 0.0359 & 0.1305 & 0.0454 \\
\hline \multirow[t]{2}{*}{ DM } & $\mathrm{P}$ & & & 1.0000 & -0.0151 & $0.1471 *$ & $0.1933 * *$ & -0.0094 & 0.0229 & $-0.2127 * *$ & $0.1928 * *$ & 0.0168 & -0.0301 \\
\hline & G & & & 1.0000 & -0.0270 & 0.2156 & 0.4086 & 0.0035 & 0.2720 & -0.3787 & 0.3541 & 0.0212 & -0.0180 \\
\hline \multirow[t]{2}{*}{ PH } & $\mathrm{P}$ & & & & 1.0000 & 0.0529 & -0.1004 & -0.0802 & 0.0475 & -0.0692 & 0.0662 & -0.0320 & $-0.2878 * * *$ \\
\hline & G & & & & 1.0000 & 0.0243 & -0.0949 & -0.0863 & 0.0623 & -0.1055 & 0.0969 & -0.0377 & -0.3031 \\
\hline \multirow[t]{2}{*}{ NPBPP } & $\mathrm{P}$ & & & & & 1.0000 & 0.0015 & $0.1700 *$ & $0.1530 *$ & $0.1852 * *$ & 0.0427 & 0.1173 & $0.2182 * *$ \\
\hline & G & & & & & 1.0000 & 0.0966 & 0.2554 & 0.3448 & 0.3175 & 0.0679 & 0.1448 & 0.3296 \\
\hline \multirow[t]{2}{*}{ NSBPP } & $\mathrm{P}$ & & & & & & 1.0000 & $0.1708 *$ & 0.1020 & $-0.1838 * *$ & $0.1391 *$ & -0.1031 & $0.1580^{*}$ \\
\hline & G & & & & & & 1.0000 & 0.2575 & 0.1030 & -0.3581 & 0.4985 & -0.1473 & 0.1642 \\
\hline NCPP & $\mathrm{P}$ & & & & & & & 1.0000 & -0.0315 & $0.1969 * *$ & $0.2557 * * *$ & -0.0003 & $0.6555^{* * *}$ \\
\hline \multirow[t]{2}{*}{ NCPP } & $\mathrm{P}$ & & & & & & & & 1.0000 & -0.1333 & -0.0036 & -0.1217 & 0.0841 \\
\hline & G & & & & & & & & 1.0000 & -0.1541 & 0.0913 & -0.1480 & 0.1074 \\
\hline \multirow[t]{2}{*}{$1000 \mathrm{SW}$} & $\mathrm{P}$ & & & & & & & & & 1.0000 & -0.0613 & 0.0640 & $0.1695^{*}$ \\
\hline & G & & & & & & & & & 1.0000 & -0.1553 & 0.0979 & 0.2381 \\
\hline \multirow[t]{2}{*}{ HI (\%) } & $\mathrm{P}$ & & & & & & & & & & 1.0000 & 0.0261 & $0.1676^{*}$ \\
\hline & G & & & & & & & & & & 1.0000 & 0.0667 & 0.2189 \\
\hline \multirow[t]{2}{*}{ OC $(\%)$} & $\mathrm{P}$ & & & & & & & & & & & 1.0000 & $-0.1371^{*}$ \\
\hline & G & & & & & & & & & & & 1.0000 & -0.1521 \\
\hline
\end{tabular}

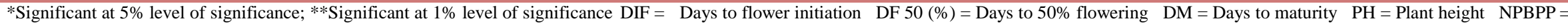

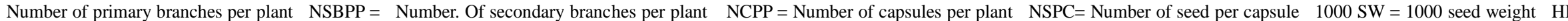
$(\%)=$ Harvest index $(\%)$, OC $(\%)=$ Oil content $(\%)$, SYPP $=$ Seed yield per plant 
Table.2 Genotypic and Phenotypic path coefficient analysis showing direct and indirect effects for yield and yield related traits in sesame genotypes

\begin{tabular}{|c|c|c|c|c|c|c|c|c|c|c|c|c|c|}
\hline \multicolumn{2}{|c|}{ Character } & DIF & DF $50(\%)$ & DM & PH & NPBPP & NSBPP & NCPP & NSPC & $1000 \mathrm{SW}$ & HI (\%) & OC (\%) & SYPP \\
\hline \multirow[t]{2}{*}{ DIF } & $\mathbf{P}$ & -0.2882 & -0.2821 & -0.0082 & 0.0499 & 0.0503 & 0.0302 & -0.0599 & 0.0358 & -0.0018 & -0.0110 & -0.0260 & 0.0576 \\
\hline & G & -0.6607 & -0.6558 & -0.0124 & 0.1271 & 0.2109 & 0.0954 & -0.1419 & 0.1222 & 0.0006 & -0.0100 & -0.0608 & 0.0503 \\
\hline \multirow{2}{*}{$\begin{array}{c}\text { DF } 50 \\
(\%)\end{array}$} & $\mathbf{P}$ & 0.2176 & 0.2223 & 0.0101 & -0.0396 & -0.0384 & -0.0278 & 0.0432 & -0.0308 & -0.0027 & 0.0123 & 0.0274 & 0.0547 \\
\hline & G & 0.6038 & 0.6084 & 0.0217 & -0.1250 & -0.2001 & -0.0876 & 0.1211 & -0.1131 & -0.0314 & 0.0219 & 0.0794 & 0.0454 \\
\hline \multirow[t]{2}{*}{ DM } & $\mathbf{P}$ & -0.0014 & -0.0023 & -0.0508 & 0.0008 & -0.0075 & -0.0098 & 0.0005 & -0.0012 & 0.0108 & -0.0098 & -0.0009 & -0.0301 \\
\hline & G & -0.0019 & -0.0037 & -0.1023 & 0.0028 & -0.0221 & -0.0418 & -0.0004 & -0.0278 & 0.0388 & -0.0362 & -0.0022 & -0.0180 \\
\hline \multirow[t]{2}{*}{ PH } & $\mathbf{P}$ & 0.0458 & 0.0471 & 0.0040 & -0.2642 & -0.0140 & 0.0265 & 0.0212 & -0.0126 & 0.0183 & -0.0175 & 0.0085 & -0.2878 \\
\hline & $\mathbf{G}$ & 0.0579 & 0.0618 & 0.0081 & -0.3008 & -0.0073 & 0.0285 & 0.0260 & -0.0187 & 0.0317 & -0.0291 & 0.0113 & -0.3031 \\
\hline \multirow[t]{2}{*}{ NPBPP } & $\mathbf{P}$ & -0.0214 & -0.0212 & 0.0181 & 0.0065 & 0.1229 & 0.0002 & 0.0209 & 0.0188 & 0.0228 & 0.0053 & 0.0144 & 0.2182 \\
\hline & G & -0.0683 & -0.0703 & 0.0461 & 0.0052 & 0.2139 & 0.0207 & 0.0546 & 0.0738 & 0.0679 & 0.0145 & 0.0310 & 0.3296 \\
\hline \multirow[t]{2}{*}{ NSBPP } & $\mathbf{P}$ & -0.0010 & -0.0012 & 0.0018 & -0.0010 & 0.0000 & 0.0095 & 0.0016 & 0.0010 & -0.0017 & 0.0013 & -0.0010 & 0.1580 \\
\hline & G & 0.0184 & 0.0183 & -0.0520 & 0.0121 & -0.0123 & -0.1274 & -0.0328 & -0.0131 & 0.0456 & -0.0635 & 0.0188 & 0.1642 \\
\hline \multirow[t]{2}{*}{ NCPP } & $\mathbf{P}$ & 0.1282 & 0.1199 & -0.0058 & -0.0494 & 0.1048 & 0.1053 & 0.6166 & -0.0194 & 0.1214 & 0.1576 & -0.0002 & 0.6555 \\
\hline & G & 0.1323 & 0.1227 & 0.0021 & -0.0532 & 0.1574 & 0.1587 & 0.6163 & -0.0313 & 0.1657 & 0.1923 & 0.0056 & 0.6723 \\
\hline \multirow[t]{2}{*}{ NCPP } & $\mathbf{P}$ & -0.0096 & -0.0107 & 0.0018 & 0.0037 & 0.0118 & 0.0079 & -0.0024 & 0.0773 & -0.0103 & -0.0003 & -0.0094 & 0.0841 \\
\hline & G & -0.0120 & -0.0120 & 0.0176 & 0.0040 & 0.0223 & 0.0067 & -0.0033 & 0.0647 & -0.0100 & 0.0059 & -0.0096 & 0.1074 \\
\hline \multirow[t]{2}{*}{$1000 \mathrm{SW}$} & $\mathbf{P}$ & 0.0002 & -0.0003 & -0.0053 & -0.0017 & 0.0046 & -0.0045 & 0.0049 & -0.0033 & 0.0247 & -0.0015 & 0.0016 & 0.1695 \\
\hline & G & 0.0000 & 0.0014 & 0.0104 & 0.0029 & -0.0087 & 0.0098 & -0.0074 & 0.0042 & -0.0273 & 0.0042 & -0.0027 & 0.2381 \\
\hline \multirow[t]{2}{*}{ HI (\%) } & $\mathbf{P}$ & 0.0013 & 0.0019 & 0.0068 & 0.0023 & 0.0015 & 0.0049 & 0.0090 & -0.0001 & -0.0022 & 0.0351 & 0.0009 & 0.1676 \\
\hline & G & 0.0020 & 0.0048 & 0.0476 & 0.0130 & 0.0091 & 0.0671 & 0.0420 & 0.0123 & -0.0209 & 0.1345 & 0.0090 & 0.2189 \\
\hline \multirow[t]{2}{*}{$\mathrm{OC}(\%)$} & $\mathbf{P}$ & -0.0138 & -0.0188 & -0.0026 & 0.0049 & -0.0179 & 0.0157 & 0.0000 & 0.0185 & -0.0098 & -0.0040 & -0.1524 & -0.1371 \\
\hline & G & -0.0213 & -0.0303 & -0.0049 & 0.0087 & -0.0336 & 0.0342 & -0.0021 & 0.0343 & -0.0227 & -0.0155 & -0.2319 & -0.1521 \\
\hline
\end{tabular}

Residual effect $=0.619$ Note: Diagonal bold figure are the direct effect and the off diagonal are indirect effects

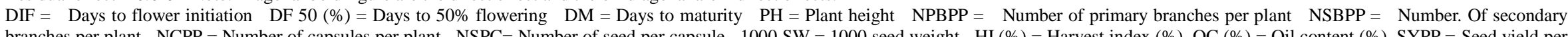

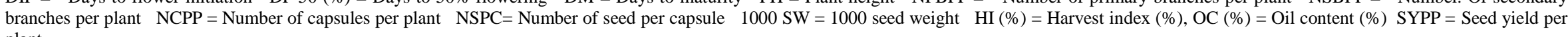
plant 
Fig.1 Correlation between plant traits

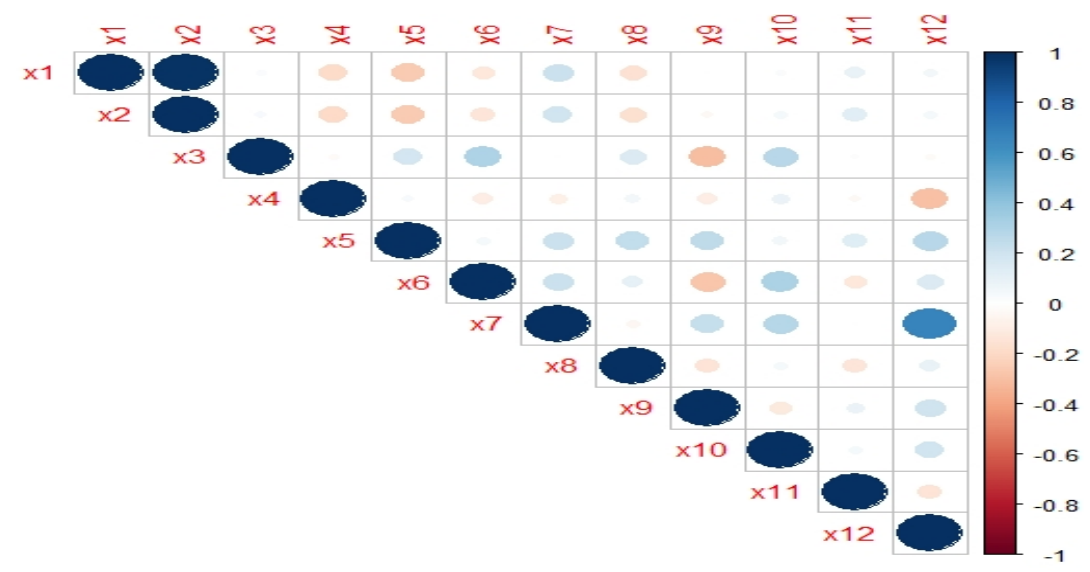

Fig.2 Genotypic path diagram for seed yield per plant

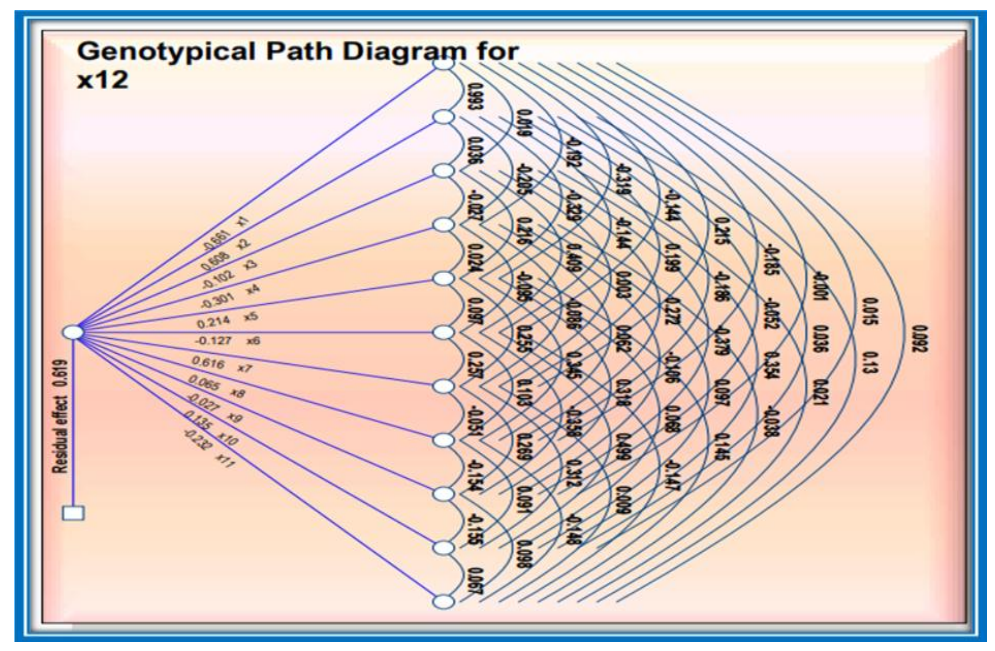

Fig.3 Phenotypic path diagram for seed yield per plant

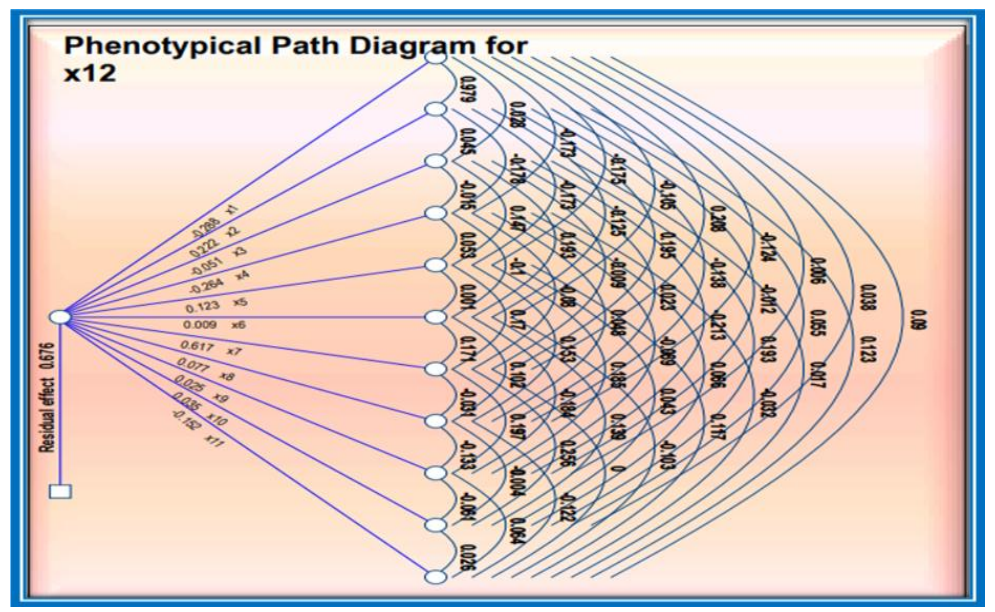


Study revealed that seed yield per plant showed highly positive significant correlation with number of capsules per plant and number of primary branches per plant and significant correlation with 1000 seed weight, harvest index and number of secondary branches per plant. While, significant negative correlation was exhibited with plant height and oil content \%. Correlation coefficients of various traits are exhibited in Table 1 (Fig -1).

The association between seed yield and its contributing characters indicated that days to flower initiation showed positive significant association with days to $50 \%$ flowering and number of capsules per plant, while, negative association was observed with plant height and number of primary branches. Days to $50 \%$ flowering expressed high positive significant association with days to $50 \%$ flowering followed by number of capsules per plant, while, negative association was exhibited with plant height and number of primary branches per plant. Days to maturity expressed positive significant association with number of secondary branches per plant, number of primary branches per plant and harvest index (\%), whereas, negative association was exhibited by 1000 seed weight (g). Plant height expressed negative significant association with days to $50 \%$ flowering and days to flower initiation. Number of primary branches per plant expressed positive association with thousand seed weight, number of capsule per plant, number of seeds per capsule and days to maturity, while, negative association was observed with days to flower initiation and days to $50 \%$ flowering. Number of secondary branches per plant expressed positive significant association with days to maturity, number of capsules per plant and harvest index (\%), while, it recorded negative association with thousand seed weight (g). Number of capsules per plant expressed positive significant association with harvest index, days to flower initiation, thousand seed weight, days to $50 \%$ flowering, number of secondary branches per plant and number of primary branches per plant. Number of seeds per capsule showed significant positive correlation with primary branches per plant, while, negative association was exhibited with days to $50 \%$ flowering. 1000 seed weight showed significant positive correlation with number of capsule per plant and number of primary branches per plant while, negative association with days to maturity. Harvest index showed significant positive correlation with number of capsules per plant, days to maturity and number of secondary branches per plant. These findings are in accordance to Goudappagoudra et al., (2011), Abate and Mekbib (2015), Saxena and Bisen (2016), Kordestani et al., (2009) for 1000 seed weight and number of capsules per plant; Gangadhara et al., (2012) for capsules per plant and branches per plant; Fazal et al., (2015) for branches per plant, capsules per plant, seeds per capsule and 1000 seed weight and Singh et al., (2017) for number of capsules per plant and number of secondary branches per plant. Seed yield per plant showed high significant negative correlation with plant height and oil content, which is contrast to the findings of Shekhawat et al., (2013) and Singh et al (2017). Overall correlation study indicated that the traits viz., number of capsules per plant, number of primary branches per plant, 1000 seed weight, harvest index and number of secondary branches per plant may play important role in the improvement of seed yield.

Path coefficient analysis (Table 2) was studied considering twelve component traits, out of which traits viz., number of capsules per plant, days to $50 \%$ flowering, number of primary branches per plant, number of seeds per capsule and harvest index showed significant positive direct effect with seed yield per plant. Similar findings have also 
been obtained by Parameshwarappa et al., (2009) and Ibrahim and Khidir (2012) for number of capsules per plant, Gangadhara et al., (2012), Abate and Mekbib (2015) for harvest index; Bharathi et al., (2015) and Abhijatha et al., (2017) for number of seeds per capsule and number of capsules per plant.

While indirect effect reported in days to flower initiation exhibited positive indirect effect on seed yield per plant via number of primary branches per plant, plant height, number of seeds per capsule, number of secondary branches per plant, whereas, negative indirect effect was exhibited via days to $50 \%$ flowering, number of capsules per plant and oil content. Days to $50 \%$ flowering exhibited positive indirect effect on seed yield per plant via number of capsules per plant, oil content, harvest index (\%) and days to maturity, whereas negative indirect effect was exhibited through number of primary branches per plant, plant height, number of secondary branches per plant and thousand seed weight.

Days to maturity exhibited positive indirect effect on seed yield per plant via plant height, thousand seed weight and negative indirect effect was exhibited through days to flower initiation, number of primary branches per plant, harvest index, number of seeds per capsule, oil content and number of capsules per plant. Plant height exhibited positive indirect effect on seed yield per plant via thousand seed weight, number of secondary branches per plant, number of capsules per plant, oil content, while negative indirect effect was exhibited via through harvest index, number of seeds per capsule and number of primary branches per plant. Number of primary branches per plant exhibited positive indirect effect on seed yield per plant via number of seeds per capsule, thousand seed weight, number of capsules per plant, number of secondary branches per plant, oil content and harvest index. Number of secondary branches per plant exhibited positive indirect effect on seed yield per plant via thousand seed weight and oil content; negative indirect effect via harvest index, number of capsules per plant and number of seeds per capsule.

Number of capsules per plant exhibited positive indirect effect on seed yield per plant via harvest index, thousand seed weight and oil content. These positive direct effects observed with seed yield were in accordance with the reports of Parameshwarappa et al., (2009) and Ibrahim and Khidir (2012) for number of capsules per plant, Gangadhara et al., (2012), Abate and Mekbib (2015) for harvest index; Bharathi et al., (2015) and Abhijatha et al., (2017) for number of seeds per capsule and number of capsules per plant. The path analysis of the present investigation revealed that substantial negative direct effect on seed yield was observed by days to flower initiation, plant height, oil content (\%) thousand seed weight, number of secondary branches per plant, days to maturity and number of secondary branches per plant. These findings were similar with the reports of Thiyagu et al., (2007) for 1000 seed weight, Gangadhara et al., (2012) for oil content and days to maturity; Abate and Mekbib (2015) for days to maturity.

The path analysis of the present investigation revealed that substantial negative direct effect was observed by days to flower initiation, plant height, oil content (\%), 1000 seed weight, number of secondary branches per plant, days to maturity and number of secondary branches per plant. Similar findings have also been obtained by Thiyagu et al., (2007) for 1000 seed weight, Gangadhara et al., (2012) for oil content and days to maturity; Abate and Mekbib (2015) for days to maturity. 
In conclusion this experiment, the relationship study through path analysis and correlation revealed that characters such as number of capsules per plant, number of primary branches per plant and harvest index should be considered as the main selection parameters for formulating high yielding plant ideotype.

\section{Acknowledgements}

This study was funded by the Department of Plant Breeding \& Genetics, College of Agricultural Jabalpur (M.P.) University, Jawaharlal Nehru Krishi Vishwa Vidyalaya, Jabalpur, India. The author thanks Head of the Department of Genetics and Plant Breeding and other concern personnel for valuable guide and support.

\section{Conflict of interest}

Authors would hereby like to declare that there is no conflict of interests that could possibly arise.

\section{References}

Abate M and Mekbib F 2015 Assessment of genetic variability and character association in Ethopian low-altitude sesame (Sesamum indicum L.) genotypes. Journal of Advanced Studies in Agricultural, Biological and Environmental Sciences (JABE) 2(3): 55-66.

Abhijatha A, Kuduka Madhukar and Arya K 2017 Evaluation of Sesame (Sesamum indicum L.) genotypes to the shaded uplands of Southern region. Int.J.Curr.Microbiol.App.Sci. $\quad$ 6(7): 332-339.

Bharathi D, Rao VT Venkanna, V Bhadru D 2015 Association analysis in sesame (Sesamum indicum L.). International Journal of Applied Biology and
Pharmaceutical Technology 6 (1): 209212.

Dewey DR and Lu KH 1959 Correlation and path coefficient analysis of components of crested wheat grass seed production. Agronomy Journal 51: 515-518.

Fazal A, Mustafa HSB Hasan EU Anwar M Tahir MHN and Sadaqat HA 2015 Interrelationship and path coefficient analysis among yield and yield related traits in sesame (Sesamum indicum L.). Nature and Science. 13(5): 27-32.

Gangadhara K, Chandra P, Bharamaraj B, Shadakshari TV, Yathish KR and Rajesh AM 2012 Genetic divergence, genetic advance and heritability in sesame (Sesamum indicum L.). Bioinfolet 9 (4): 457-462.

Goudappagoudra R, Lokesha R and Ranganatha ARG 2011 Trait association and path coefficient analysis for yield and yield attributing traits in sesame (Sesamum indicum L.). Electronic Journal of Plant Breeding 2: 448-452.

Ibrahim SE and Khidir MO 2012 Genotypic correlation and path coefficient analysis of yield and some yield components in sesame (Sesamum indicum L.). International Journal of Agricultural Sciences 2 (8): 664-670.

Kordestani R, Mohammadi-Nejad G, Tohidinejad E, Rezaie S, Farahbakhsh $\mathrm{H}$, Zareie S, Kamali N and Kamyabi A 2009 Yield potential assessment of different Iranian sesame landraces under various levels of Iron in Jiroft. Plant Ecophysiology 2: 85-89

Miller D A, Williams JC, Robinson HF and Comstock KB 1958 Estimates of genotypic and environmental variances and co variances in upland cotton and their implication in selection. Agronomy Journal 50: 126-131.

Parameshwarappa SG, Palakshappa MG, 
Salimath PM and Parameshwarappa KG 2009 Studies on genetic variability and character association in germplasm collection of sesame (Sesamum indicum L.). Karnataka Journal of Agriculture Sciences 22 (2): 252-254.

Saxena K and Bisen R 2016 Genetic variability correlation and path analysis studies for yield and yield component traits in sesamum (Sesamum indicum L.). International Journal of Agriculture Sciences 8 (61): 34873489.

Shekhawat RS, Meena SK and Singh B 2013 Genetic divergence analysis in sesame. Indian Research Journal of Genetics and Biotechnology 5 (2): 105-110.

Singh A, Bisen R and Tiwari A 2017 Asseing interrelationship of sesame genotypes and their traits using cluster analysis and principal component analysis. International Journal on Chemical Studies 6(1): 2151-2155.

Thiyagu K, Kandasamy G, Manivannan N, Muralidharan V and Uma D 2007 Correlation and path analysis for oil yield and its components in cultivated sesame (Sesamum indicum L.). Agriculture Science Digest 27 (1): 62 64.

\section{How to cite this article:}

Ayushi Jaiswal and Rajani Bisen. 2021. Estimation of Correlation and Path Analysis between Seed Yield and Various Quantitative Traits in Black Sesame (Sesamum indicum L.). Int.J.Curr.Microbiol.App.Sci. 10(01): 893-901. doi: https://doi.org/10.20546/ijcmas.2021.1001.107 